\title{
SISTEM CERDAS PENENTUAN REKOMENDASI PEMILIHAN JALUR ANGKOT KOTA MALANG
}

\author{
${ }^{[1]}$ Usman Nurhasan, ${ }^{[2]}$ Eka Larasati Amalia, ${ }^{[3]}$ Elly Setyo Astuti \\ [1] [2] [3] Politeknik Negeri Malang
}

\begin{abstract}
Abstrak: Penelitian ini mendiskusikan penerapan Struktur Diskrit, khususnya Graf, untuk menentukan jalur tercepat bagi transportasi umum Angkutan Kota (angkot). Jalur tercepat adalah jalur dengan jeda keterlambatan (latency) terkecil diantara dua node. Ada berbagai cara untuk menemukan jalur tercepat, namun tujuannya tetap sama yaitu untuk menemukan waktu perjalanan yang terpendek. Penelitian ini menerepkan metode $A^{*}$ untuk mencari jalur tercepat. Metode ini digunakan karena sederhana dan dapat mengakomodasi perhitungan dengan satu variabel, seperti jarak. Aplikasi yang dihasilkan dalam penelitian ini akan sangat berguna bagi pengguna transportasi umum.
\end{abstract}

Kata Kunci: A*, A-Star, jarak terdekat, transportasi umum.

\section{Pendahuluan}

Transportasi merupakan sarana bagi manusia untuk melakukan perjalanan dari satu tempat ke tempat lainnya. Saat ini transportasi dapat dilakukan melalui 3 jalur alternatif (darat, laut dan udara). Tidak semua orang memiliki kemampuan untuk menyediakan sarana transportasi pribadi yang menyebabkan terciptanya angkutan umum dengan masing-masing rute yang dilalui khususnya Kota Malang. Di Kota Malang terdapat berbagai macam angkutan umum dengan rute dan jalurnya masingmasing. Namun, berdasarkan observasi peneliti, hal tersebut tidak dilengkapi dengan ketersediaan informasi trayek dan jalur secara memadai. Hal ini menyebabkan tidak semua pengguna mengetahui jalur angkutan umum secara pasti.

Permasalah optimasi merupakan permasalahan yang sering sekali ditemui dalamkehidupan sehari-hari. Hal ini tidak lepas dari sifat dasar manusia yang selalu ingin mendapat keuntungan semaksimal mungkin dan memperoleh kerugian seminimal mungkin. Jika kita membicarakan permasalahan mengenai rute atau jalur yang menghubungkan tempat-tempat tertentu maka kita sering menggambarkannya dengan bulatan untuk memvisualisasikan tempat dan garis untuk jalan/rute. Representasi semacam ini merupakan suatu representasi dari graf. 
Graf adalah himpunan simpul yang dihubungkan dengan suatu garis dimana garis tersebut menghubungkan dengan tepat ke 2 simpul sehingga simpul-simpul ini saling berhubungan. Dalam kehidupan sehari-hari banyak sekali persoalan yang diimplementasikan dengan graf. Bidang-bidang yang menggunakan penerapan graf antara lain Switching network, Coding theory, Electrical analysis, Operation research, aljabar, computer science, dan kimia.Banyak sekali aplikasi yang mengunakan graf sebagai alat untuk merepresentasikan atau memodelkan persoalan sehingga persoalan itu dapat diselesaikan dengan baik. Aplikasi-aplikasi tersebut misalnya menentukan lintasan terpendek (the shortest path problem), traveling salesman problem, chinese postman problem, graf colouring, Making a road system one-way, rangking the participants in a tournament, dan masih banyak lagi. Dalam kesempatan ini peneliti mencoba mengulas tentang persoalan menentukan lintasan terpendek (The Shortest Path Problem).

Menurut teori graf, persoalan lintasan terpendek adalah suatu persoalan untuk mencarilintasan antara dua buah simpul pada graf berbobot yang memiliki gabungan nilai jumlahbobot pada sisi graf yang dilalui dengan jumlah yang paling minimum. Persoalan lintasanterpendek ini banyak sekali dijumpai di kehidupan sehari-hari. Aplikasi yang paling sering ditemui adalah pada bidang transportasi, seperti pada pencarian rute terbaik untuk menempuh dua kota.

Menurut teori graf, persoalan lintasan terpendek adalah suatu persoalan untuk mencari lintasan antara dua buah simpul pada graf berbobot yang memiliki gabungan nilai jumlah bobot pada sisi graf yang dilalui dengan jumlah yang paling minimum atau dapat dinyatakan juga sebagai berikut. Diberikan sebuah graf berbobot (dengan himpunan simpul $\mathrm{V}$, himpunan sisi $\mathrm{E}$, dan fungsi bobot bernilai bilangan riil yang dapat ditulis dengan $\mathrm{f}: \mathrm{E} \rightarrow \mathrm{R}$ ), dan diberikan elemen $\mathrm{v}$ dari $\mathrm{V}$, sehingga dapat dicari sebuah lintasan $P$ dari $v$ ke setiap $\mathrm{v}^{\prime}$ dari $\mathrm{V}$, sehingga $\Sigma \mathrm{f}(\mathrm{p}) \mathrm{p} \in \mathrm{P}$ adalah nilai minimum dari semua lintasan yang menghubungkan $\mathrm{v}$ ke $\mathrm{v}$ '.

Persoalan lintasan terpendek merupakan salah satu persoalan optimasi yeng menggunakan graf berbobot, dimana bobot pada setiap sisi graf tersebut dapat kita gunakan untuk menyatakan jarak kota, waktu pengiriman pesan, ongkos pembangunan, dan sebagainya.

\section{Aplikasi dari Persoalan lintasan terpendek pada Graf}

Ada beberapa macam persoalan lintasan terpendek, antara lain sebagai berikut.

1. Lintasan terpendek antara dua buah simpul tertentu.

2. Lintasan terpendek antara semua pasangan simpul.

3. Lintasan terpendek dari simpul tertentu ke semua simpul yang lain. 
4. Lintasan terpendek antara dua buah simpul yang melalui beberapa simpul tertentu.

Aplikasi persoalan penentuan lintasan terpendek ini banyak sekali kita jumpai dalamkehidupan sehari-hari di antaranya sebagai berikut.

a. Menentukan rute / jalur terbaik yang harus ditempuh dari suatu kota menuju ke kotayang lain.

b. Menentukan jalur komunikasi 2 buah terminal komputer.

c. Menentukan jalur penerbangan dunia yag paing efektif untuk dilakukan.

Informasi dapat diolah dan disampaikan dengan memanfaatkan media website. Penggunaan media ini didasarkan pada fleksibilitas pengolahan data. Data yang diolah pada website, dapat diakses oleh seluruh user dengan memperhatikan hak aksesnya. Proses operasional website yang mudah dengan cara menuliskan url atau alamat yang dituju, membuat aplikasi berbasis web memiliki proses yang cepat dan ringan. Hal ini dikarenakan seluruh proses dilakukan oleh server. Dengan keunggulan ini, website dapat diimplementasikan untuk pengolahan data secara realtime.

Atas dasar permasalahan-permasalahan di atas, penulis akan mencoba untuk membuat sebuah aplikasi berbasis web yang dapat memberikan informasi mengenai jalur atau rute angkutan kota Malang, memvisualisasikannya dalam bentuk peta, serta dapat mencari rute terpendek dari posisi keberangkatan di mana pengguna berada. Aplikasi ini menggunakan algoritma Dijkstra untuk dapat memberikan rute yang efisien. Algoritma Dijkstra dipilih oleh penulis karena jika dibandingkan dengan algoritma pencarian konvensional lainnya seperti Bellman-Ford dan Floyd-Warshall, algoritma Dijkstra memiliki kompleksitas ruang dan waktu.

\section{Metode Penelitian}

\section{A. Tempat dan Waktu Penelitian}

Penelitian ini dilaksanakan di Kota Malang, tepatnya di jalur angkot yang ada di Kota Malang. Berikut penjelasan mengenai jalur angkot di Kota Malang.

Angkutan umum kota Malang menghubungkan 3 terminal besar, yaitu terminal Hamid Rusdi (dulunya Terminal Gadang), Terminal Arjosari berada di pintu masuk kota dari arah Surabaya, dan Terminal Landungsari berada di jalur menuju kota Batu. Selain 3 terminal utama, terdapat beberapa terminal kecil seperti terminal Tlogowaru, Mulyorejo. Angkutan umum yang berada dan beroperasi di seluruh wilayah kotamadya Malang, semua berwarna Biru.Yang membedakan tiap jalur adalah garis strip pada body angkot dan juga kode jalur yang berada di sisi dan depan mobil angkot. Inilah beberapa Jalur angkutan kota di Malang beserta rute nya. 


\section{a. Jalur LDG/ LDH (Landungsari-Dinoyo-Gadang/ Hamidrusdi)}

Terminal Landungsari - Jl. Tlogomas - Jl. MT Haryono - Jl. M. Panjaitan Jl. B. Slamet Riyadi - Jl. Basuki Rahmat - Jl. Merdeka Barat - Jl. Kauman Jl. syaif Al- Qodri - Jl. Ade Irma Suryani - Jl. Pasar Besar - Jl. Sersan harun - Jl. M. Yamin - J1. sartono S.H. - J1. Kol. Sugiono - Terminal Gadang/ hamidrusdi

\section{b. Jalur LG/ LH (Landungsari - Gadang/ Hamid Rusdi)}

Terminal Landungsari - Jl. Tlogo Mas - Jl. Mayjend Haryono - Jl. Sumber Sari - J1. Bendungan Sutami - J1. Surabaya - Jl. Bondowoso - J1. Gading - Jl. Wilis - Jl. Panderman - Jl. AR Hakim - Jl. Merdeka Utara - Jl. Merdeka Selatan - Jl. Wiryopranoto - Jl. Sultan Syahrir - Jl. Kyai Tamin - Jl. Sartono SH - Jl. Peltu Sujono - J1. Susanto - J1. Niaga - Jl. Sonokeling - J1. Janti - Jl. S. Supriyadi - Jl. Satsuit Tubun - Terminal Gadang

\section{c. Jalur GA/ HA (Gadang/ Hamidrusdi - Arjosari)}

Terminal Gadang - Jl. Satsuit Tubun - Jl. S Supriyadi - J1. Arif Margono - J1. Ade Irma Suryani -Jl. KH Wahid Hasyim -Jl. Kauman - Jl. Hasyim Asyhari - Jl. AR Hakim - Jl. Merdeka Utara - Jl. S Wiryop ranoto - Jl. Mojopahit Jl. Tugu - Jl. Untung Suropati - Jl. Pajajaran - Jl. Truno Joyo - Jl. Cokroaminoto - J1. Dr Cipto - Jl. Pang Sudirman - J1. WR Supratman - Jl. Letjend Sutoyo - J1. Letjend S. Parman - Jl. Jend A. Yani - Jl. R Intan Terminal Arjosari

\section{d. Jalur GL/ HA (Gadang/ Hamid Rusdi - Landungsari)}

Terminal Gadang - Jl. S Tubun -Jl. S. Supriadi -Jl. Janti -Sonokeling. -Jl. Niaga -Jl. Susanto -Jl. Halmahera -J1. Sampo -Jl. Kalimantan -Jl. Sulawesi Jl. Yulius Usman -Jl. Arief Margono -Jl. KH. Hasyim Asyari -Jl. Kawi -Jl. Ijen -Jl. Retawu -Jl. Gede -Jl. Jakarta -Jl. Garut -Jl. Bandung -Jl. Veteran Jl. Sumbersari -Jl. Gajayana -Jl. MT. Hartono -Jl. Raya Tlogomas -Terminal Landungsari.

\section{e. Jalur GM/ HM (Gadang/ Hamid Rusdi - Mulyorejo)}

Terminal Gadang - Jl. Kol. Sugiono . - Jl. Susanto - Jl. Irian Jaya - Jl. Tanimbar. - J1. Sulaesi. - Jl. Yulius Usman . - Jl. Syarief Al Qodri - J1. A. I Suryani - Jl. B. Katamso - Jl. Ir Rais - Jl. Jupri - Jl. Bandulan - Jl. Raya Mulyrejo - Sub Terminal Mulyorejo. 


\section{f. Jalur GML/ HML (Gadang/ Hamid Rusdi - Mergan - Landungsari)}

Terminal Gadang - Jl. Satsuit Tubun - J1. S. Supriyadi - Jl. Janti - Jl. Sono Keling - Jl. Niaga - Jl. Susanto - Jl. Halmahera - J1. Tanimbar - Jl. Sulawesi - J1. Nusakambangan - J1. Arief Margono - J1. S. Supriyadi - J1. Rajawali Term Mergan Lori - Jl. Raya Langsep - Jl. Galunggunbg - Jl. Bukit Barisan Jl. Tamboro - Jl. Tidar - Jl. Simpang Candi - Jl. Candi - J1. Ters. Sigura-gura - Jl. Belakang IAIN - Jl. Mertoijoyo Selatan - Jl. Mertojoyo - Jl. MT Haryono Gg XII- Jl. Raya Tlogomas - Terminal Landungsari

\section{g. Jalur ABG/ ABH (Arjosari - Borobudur - Gadang/ Hamid Rusdi)}

Terminal Arjosari - Jl. Simpang RP Suroso - Jl. R. Intan - J1. A. Yani - Jl. Borobudur - Jl. Sukarno Hatta - Jl. Cengkeh - Jl. Kalpataru - Jl. Melati - Jl. Mawar - Jl. Sarangan - Jl. Tawangmangu - J1. Kaliurang - J1. WR. Supratman - Jl. P. Sudirman - Jl. Pattimura - JL. Trunojoyo - Jl. Jembatan Pahlawan - Jl. Gatot Subroto - Jl. L. Martadinata - J1. Kol Sugiyono Terminal Gadang

\section{h. Jalur ADL (Arjosari - Dinoyo - Landungsari)}

Terminal Arjosari - Jl. Simpang R. Panji Suroso - Jl. Raden Intan - Jl. Jend. A. Yani - Jl. Letjen S. Parman - Jl. Letjen Sutoyo - Jl. W. R. Supratman - Jl. Panglima Sudirman - Jl. Patimura - Jl. Trunojoyo- Jl. Kertanegara - Jl. Kahuripan - Jl Semeru - Jl. Ijen - Jl. Bandung - Jl. Terusan Bogor - Jl. Mayjen Panjahitan - Jl. Mayjen Haryono - Jl. Tlogomas - Terminal Landung Sari

\section{i. Jalur AG/ AH (Arjosari - Gadang/ Hamid Rusdi)}

Terminal Arjosari - J1. Simpang R. Panji Suroso - J1. Raden Intan - J1. Jend A. Yani - J1. Letjen S. Parma - J1. Letjen Sutuyo - Jl. Jagung Suprapto - Jl. Basuki Rahmat - Merdeka Utara - Jl. Merdeka Timur - Jl. Sukarjowiryor Panoto - Jl. Pasar Besar - Jl. Sersan Harun - Jl. Prof Moh yamin - J1. Sartono $\mathrm{SH}-\mathrm{Jl}$. Kol Sugiono - Terminal Gadang

\section{j. Jalur AJG/ AJH (Arjosari - Janti - Gadang/ Hamid Rusdi)}

Terminal Arjosari - Jl. RP. Suroso - Jl. Adi Sucipto - Jl. A. Yani - Jl. S. Parman - Jl. Letjen Sutoyo - Jl. Indragiri - Jl. RT. Suryo - Jl. Hamid Rusdi Jl. Kesatrian - Jl. Terusan Pahlawan - Jl. Urip Sumoharjo - Jl. Pattimura - Jl. Trunojoyo - Jl. Jembatan Pahlawan - Jl. Ir Juanda - Jl. Zakse - Jl. RE. Martadinata - Jl. Kyai Tamin - Jl. Prof M. Yamin - JL. P. Sujono - Jl. Susanto - Jl. Niaga - Jl. Sonokeling - Jl. Janti - J1. S. Supriyadi - J1. Satsuit Tubun - Terminal Gadang 


\section{k. Jalur AMG/ AMH (Arjosari - Mergosono - Gadang/ Hamid Rusdi)}

Terminal Arjosari - Jl. Simp SP. Suroso - Jl. S. Priyo Sudarmo - Jl. RT Suryo - Jl. Hamid Rusdi - Jl. Kesatriaan Terusan - Jl. Urip Sumoharjo - Jl. P. Sudirman - Jl. Ir Juanda - Jl. Kebalon - Jl. Kol Sugiyono - Terminal Gadang

\section{Jalur AL (Arjosari - Landungsari)}

Terminal Arjosari - Jl. R. Panji Suroso - Jl. Laksda Adi Sucipto - Jl. Tenaga - Jl. Karya Timur - Jl. Mahakam - Jl. W. R. Supratman - Jl. Panglima Sudirman - Jl. Patimura - Jl. Trunojoyo - Jl. Kertanegara - Jl. Tugu - Jl. Kahuripan - J1. Semeru - Jl. Ijen - Jl. Retawu - Jl. Bondowoso - Jl. Jombang - Jl. Suroboyo - Jl. Jakarta - Jl. Bogor - Jl. Veteran - Jl. Sumbersari Terminal Landung Sari

\section{m.Jalur ASD (Arjosari - Dieng)}

Terminal Arjosari - Jl. Simpang PR. Suroso -JL. PR. Suroso -Jl. Plaosan TMR - Jl. Tlogo Grajakan -Jl. Sucipto -Jl. Simpang Batu Bara -Jl. Batu Bara -Jl. LA. Sucipto -Jl. Tembaga -Jl. Simpang Emas -Jl. Emas -Jl. Sulfat -Jl. RT. Suryo -Jl. Sanan -Jl. Barito -Jl. Mahakam -Jl. Indragiri -Jl. Letjend Sutoyo -Jl. Sarangan -Jl. Mawar -Jl. Bungur -Jl. Melati -Jl. Kalpataru -Jl. Cengkeh -Jl. Sukarno Hatta -Jl. M. Panjaitan -Jl. Bandung -Jl. Garut -Jl. Jakarta -Jl. Surabaya -Jl. Gresik -Jl. Bondowoso -Jl. Klampok Kasri -Jl. Taman Wilis -Jl. Kawi Atas -Jl. Mundu -Jl. Raya Langsep -Jl. Terusan Dieng - Puncak Dieng.

\section{n. Jalur AT (Arjosari - Tidar)}

Terminal Arjosari - J1.Raden Intan - JL.Jend.A Yani - Jl.Letjen S Parman JL.Ciliwung-Jl.S Priyosudarmo -Jl. R Tumenggung Suryo-Jl.P Sudirman- Jl. Patimura- Jl. Belakang RSU Saiful Anwar- Jl. Kahuripan - Jl. Semeru Jl.Arjuno - Jl. Kawi - Jl. Panderman - J1. Pandan - Jl. Wilis - Jl. Gading -Jl. Sangga Buana - Jl. Galunggung - Jl. Bukit Barisan - Jl. Lokon -Jl. Raya Tidar -Jl. Puncak Mandala - Jl. Esberg - Terminal Perumahan Tidar.

\section{o. Jalur MK (Madyopuro - Karang besuki)}

Terminal Madyopuro - Jl. Kiageng Gribik - Jl. Muharto - Jl. Z. Zakse - Jl. Pasar Besar - Jl. Zaenal Arifin - Jl. A Munandar - Jl. MGR Sugriwiryopranoto - Jl. Merdeka Timur - Jl. Merdeka Selatan - Jl. Kauman Jl. KH Hasyim Asyhari - Jl. Kawi - Jl. Ijen - Jl. Pahlawan Trip - Jl. Surabaya - Jl. B. Sutami - Jl. Kleseman - Karang Besuki 


\section{p. Jalur MM (Mulyorejo - Madyopuro)}

Terminal Mulyorejo - Jl. Raya Bandulan - Jl. Jupri - Jl. Raya Langsep - Jl. Raya Dieng - Jl. Kawi Atas - Jl. Kawi - Jl. A.R. Hakim - J1. Merdeka Utara Jl. MGR. Sugriwiryopranoto - Jl. Mojopahit - Jl. Tugu - Jl. Kertanegara - Jl. Trunojoyo - Jl. Pattimura - Jl. Urip Sumoharjo - Jl. M. Wiyono - Jl. Ranu Grati - Jl. Danau Toba - Jl. Ki Ageng Gribig - Terminal Madyopuro

\section{q. Jalur MT (Mulyorejo Tlogowaru)}

Terminal Mulyorejo -Jl. Sutan Syahrir -Jl. Kyai Tamim - Jl. Laks. Martadinata Jl. Gatot Subroto - J1. Ir. H. Juanda - Jl. Muharto - Jl. Ki. Ageng Gribig - Jl. Mayjen Sungkono - Jl. Wonokoyo - Terminal Tlogowaru

\section{B. Metode Metode A-Star $\left(A^{*}\right)$}

Metode $\mathrm{A}^{*}$ adalah salah satu contoh dari metode best first search. Metode A* dikembangkan pada tahun 1968 oleh Peter Hart, Nils Nilsson, dan Bertram Raphael, mereka juga menyebut metode tersebut dengan sebutan algoritma $\mathrm{A}$, dengan metode ini dan fungsi heuristic yang tepat menghasilkan sebuah hasil yang optimal, yaitu A*.

Dalam ilmu komputer, A* (dibaca : A star) adalah sebuah graph atau metode tree search yang digunakan untuk mencari jalan dari sebuah node awal ke node tujuan yang telah ditentukan, metode ini mengunakan "estimasi heuristic" $\boldsymbol{h}(\boldsymbol{n})$ pada setiap node untuk mengurutkan setiap noden berdasarkan estimasi rute terbaik yang melalui node tersebut.

Metode $\mathrm{A}^{*}$ hanya membangun rute yang mungkin digunakan untuk mencapai tujuan. Untuk mengetahui rute mana yang memungkinkan mengarah ke titik akhir, $\mathrm{A}^{*}$ menggunakan estimasi heuristik jarak dari sembarang node ke node tujuan. Prinsip algoritma ini adalah mencari jalur terpendek dari sebuah simpul awal (starting point) menuju simpul tujuan dengan memperhatikan harga (F) terkecil. Secara umum, Depth First Search (DFS) dan Breadth First Search (BFS) adalah dua kasus spesial dari metode A*. Algoritma Dijkstra's merupakan kasus spesial dari A*, dimana $\boldsymbol{h}(\boldsymbol{n})$ $=0$, untuk semua $\boldsymbol{n}$.

\section{Pseudocode Algoritma A*}

Beberapa terminologi dasar yang terdapat pada algoritma ini adalah starting point, simpul (nodes), A, open list, closed list, harga (cost), dan rintangan (unwalkable). 
1. Starting point adalah sebuah terminologi posisi awal sebuah benda.

2. A adalah simpul yang sedang dijalankan algortima pencarian jalan terpendek.

3. Simpul adalah petak-petak kecil sebagai representasi dari area pathfinding. Bentuknya dapat berupa persegi, lingkaran, maupun segitiga.

4. Open list adalah tempat menyimpan data simpul yang mungkin diakses dari starting point maupun simpul yang sedang dijalankan.

5. Closed list adalah tempat menyimpan data simpul sebelum A yang juga merupakan bagian dari jalur terpendek yang telah berhasil didapatkan.

6. Harga (F) adalah nilai yang diperoleh dari penjumlahan nilai $\mathrm{G}$, jumlah nilai tiap simpul dalam jalur terpendek dari starting point ke $\mathrm{A}$, dan $\mathrm{H}$, jumlah nilai perkiraan dari sebuah simpul ke simpul tujuan.

7. Simpul tujuan yaitu simpul yang dituju.

8. Rintangan adalah sebuah atribut yang menyatakan bahwa sebuah simpul tidak dapat dilalui oleh A.

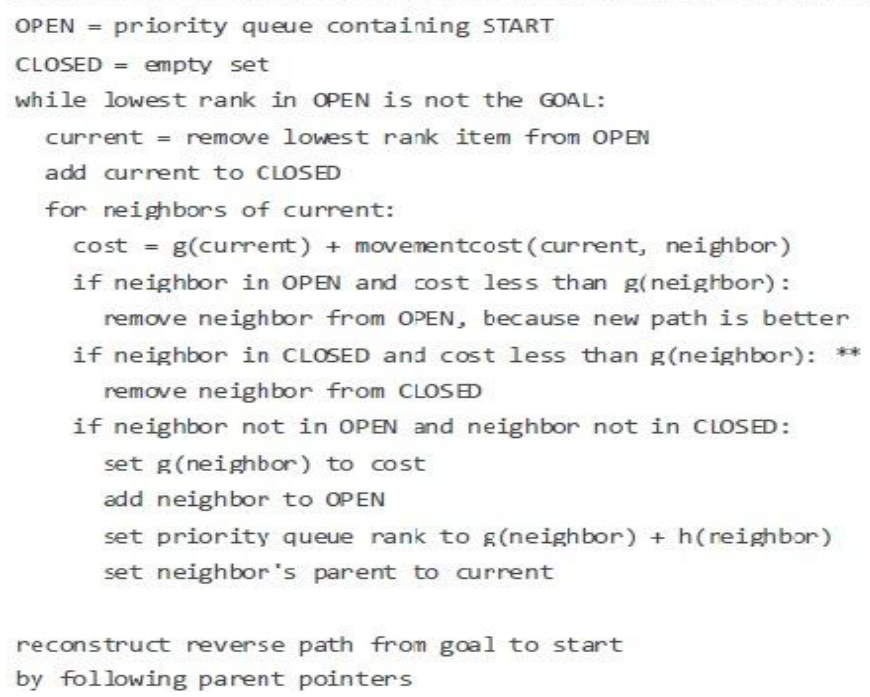

Gambar 1 Pseudocode algoritma A* (Patel, 2011)

Algoritma $\mathrm{A}^{*}$ dapat dijelaskan dengan pseudocode di bawah ini.

1. Masukan node awal ke open list

2. Loop Langkah - langkah di bawah ini.

a. Cari noden dengan nilai $\boldsymbol{f}(\boldsymbol{n})$ yang paling rendah dalam open list. Node ini sekarang menjadi current node.

b. Keluarkan current node dari open list dan masukan ke close list.

c. Untuk setiap tetangga dari current node lakukan berikut :

1) Jika tidak dapat dilalui atau sudah ada dalam close list, abaikan.

2) Jika belum ada di open list. Buat current node parent dari node tetangga ini. Simpan nilai $\boldsymbol{f}, \boldsymbol{g}$, dan $\boldsymbol{h}$ dari node ini. 
3) Jika sudah ada di open list, cek bila node tetangga ini lebih baik, menggunakan nilai $g$ sebagai ukuran. Jika lebih baik ganti parent dari node ini di open list menjadi current node, lalu kalkulasi ulang nilai $\boldsymbol{g}$ dan $\boldsymbol{f}$ dari node ini.

d. Hentikan loop jika :

1) Node goal telah ditambahkan ke openlist, yang berarti rute telah ditemukan.

2) Belum menemukan node goal sementara open list kosong atau berarti tidak ada rute.

3. Simpan rute. Secara 'backward', urut mulai dari node goal ke parent-nya terus sampai mencapai node awal sambil menyimpan node ke dalam sebuah array.

Dalam masalah pencarian rute di mana metode $A^{*}$ sering digunakan, $A^{*}$ secara bertahap membangun semua rute yang mengarah mulai dari titik awal sampai akhirnya mencapai titik akhir. Metode $A^{*}$ hanya membangun rute yang mungkin digunakan untuk mencapai tujuan. Untuk mengetahui rute mana yang memungkinkan mengarah ke titik akhir, A* menggunakan estimasi heuristic jarak dari sembarang node ke node tujuan. Dalam kasus pencarian rute, ini bisa jadi sama dengan jarak lurus antara dua titik, dimana biasanya merupakan perkiraan dari jarak jalan.

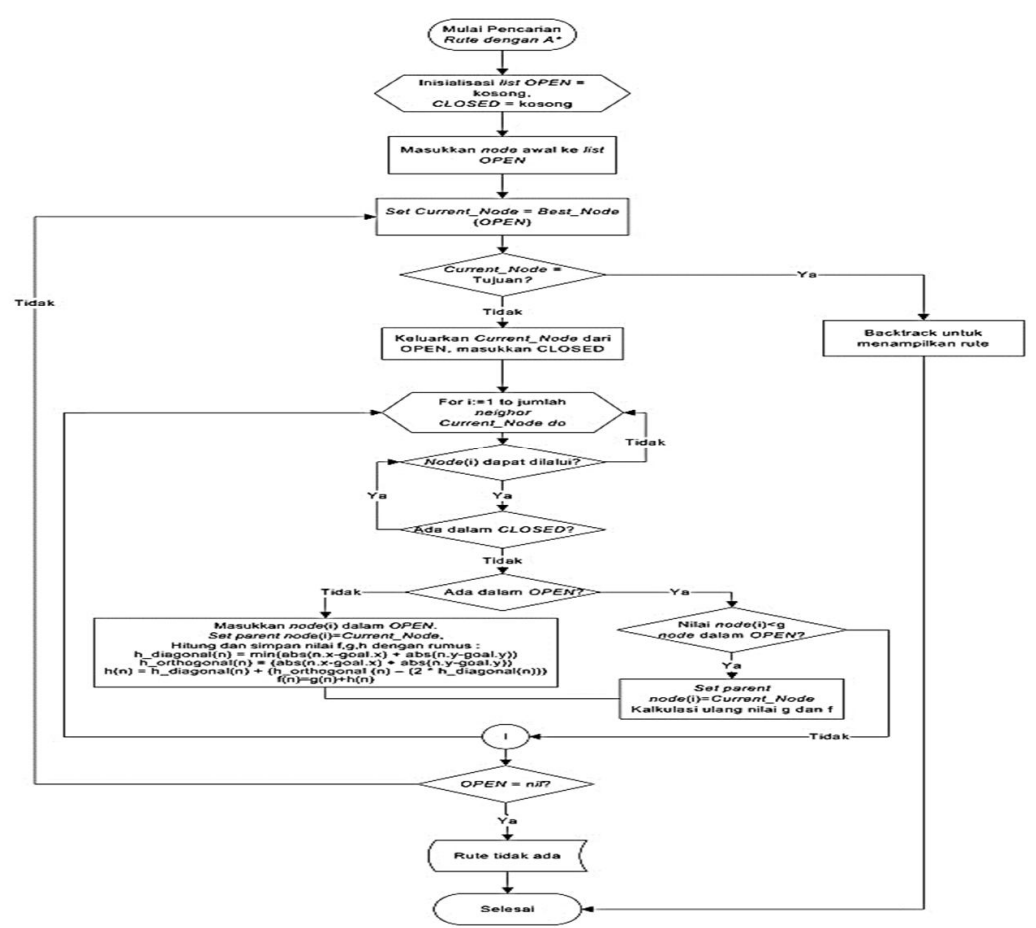

Gambar 2 Diagram Alir Metode A* 


\section{Hasil dan Pembahasan}

\section{Antarmuka Sistem}

Halaman daftar angkot berisi fasilitas yang dapat diakses oleh user maupun admin. Pada halaman ini ditampilkan gambar angkot di semua jalur dan terdapat tombol untuk mengakses jalur-jalur yang dilewati. Gambar 3 merupakan tampilan Halaman daftar angkot dari aplikasi yang dibangun. Pada Gambar 3 ditampilkan dari jalur angkot yang telah di pilih

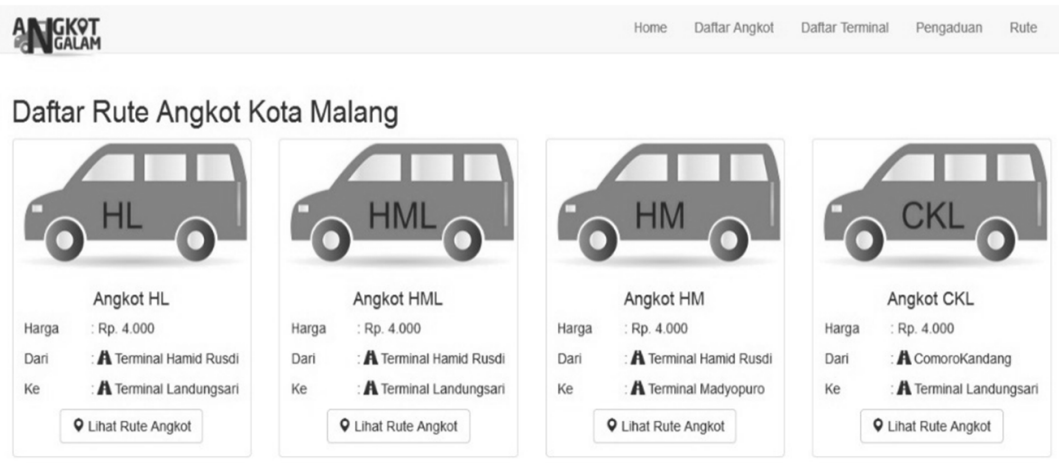

Gambar 3 Daftar Rute Angkot

Dari menu yang tersedia, dapat ditampilkan rute angkot di masing-masing jalur. Rute ini mengadopsi dari data yang di peroleh dari dinas terkait. Rute merupakan bentuk digitasi peta berdasarkan jalan yang dilalui oleh masing-masing angkot.

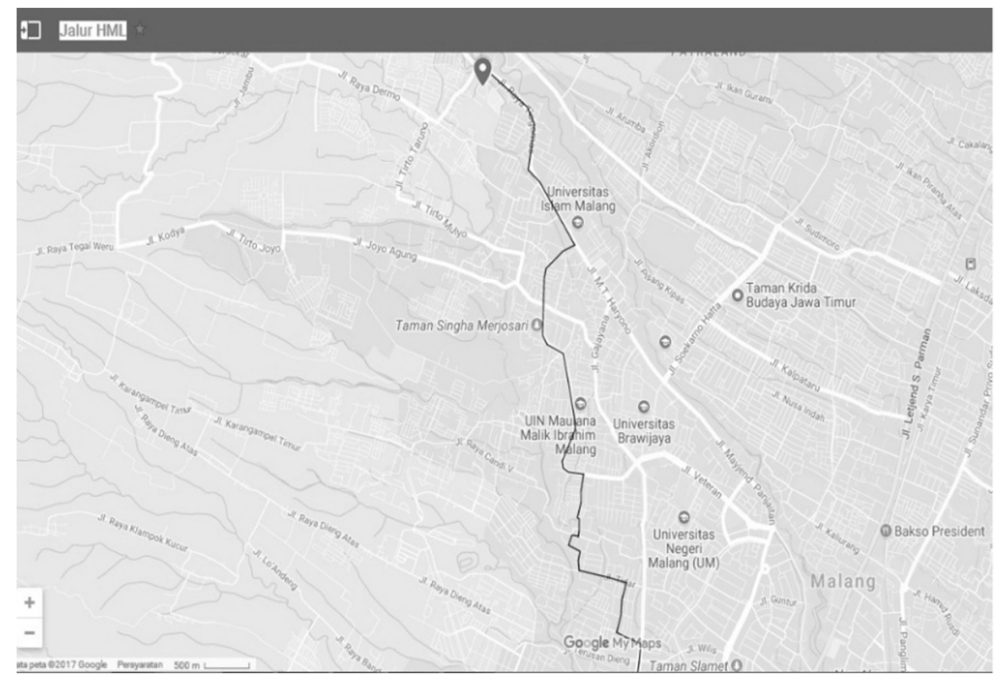

Gambar 4 Jalur Angkot 


\section{Terminal}

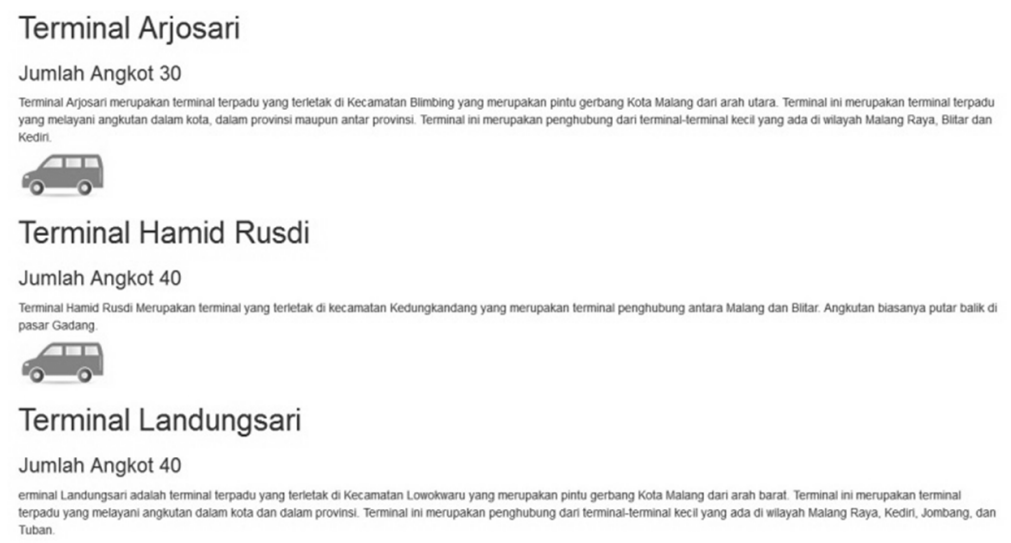

\section{Gambar 5 Daftar Terminal}

Halaman terminal berisi fasilitas yang dapat diakses oleh user maupun admin. Pada halaman ini ditampilkan daftar terminal angkot yang ada di Malang. Gambar 5 merupakan tampilan Halaman Terminal dari aplikasi yang dibangun.

\section{Pengujian dan Analisis}

(a) Daftar Node Jalan

Pada Tabel di bawah ini, ditampilkan jalur-jalur angkot, dan node-node yang akan dijadikan parameter. Jalan-jalan tersebut telah didigtasi pada peta, kemudian diberikan bobot berupa panjang jalan. Pada tabel dibawah ini ditampilkan daftar node-node jalan yang dipakai.

\section{TABEL 1 NODE JALAN}

\begin{tabular}{|c|c|c|c|c|}
\hline No. & Jalur & Jumlah & Keluar & Masuk \\
\hline 1. & ADL & 124 & $\begin{array}{l}\text { Terminal Arjosari - Jl. Simpang R. } \\
\text { Panji Suroso - Jl. Raden Intan - Jl. } \\
\text { Jend. A. Yani - Jl. Letjen S. } \\
\text { Parman - Jl. Letjen Sutoyo - Jl. } \\
\text { W. R. Supratman - Jl. Panglima } \\
\text { Sudirman - Jl. Patimura - Jl. } \\
\text { Trunojoyo- Jl. Kertanegara - Jl. } \\
\text { Kahuripan - Jl Semeru - Jl. Ijen - } \\
\text { Jl. Bandung - Jl. Terusan Bogor - } \\
\text { Jl. Mayjen Panjahitan - Jl. Mayjen } \\
\text { Haryono - Jl. Tlogomas - } \\
\text { Terminal Landung Sari }\end{array}$ & $\begin{array}{l}\text { Terminal Landung Sari }- \text { Jl. } \\
\text { Tlogomas - Jl. Mayjen Haryono - } \\
\text { Jl. Mayjen Panjahitan - Jl. Semeru } \\
\text { - Jl. Kahuripan - Jl. Tugu - Jl. } \\
\text { Kertanegara - Jl. Trunujoyo - } \\
\text { cokro Aminoto - J1. Dr. Cipto - Jl. } \\
\text { Panglima Sudirman - Jl. W. R. } \\
\text { Supratman - Jl. Letjen Sutoyo - J1. } \\
\text { Letjen S. Parman - Jl. Jend A Yani } \\
- \text { Jl. Raden Intan - terminal } \\
\text { Arjosari }\end{array}$ \\
\hline
\end{tabular}




\begin{tabular}{|c|c|c|c|c|}
\hline 2. & AL & 105 & $\begin{array}{l}\text { Terminal Arjosari - Jl. R. Panji } \\
\text { Suroso - Jl. Laksda Adi Sucipto - } \\
\text { Jl. Tenaga - Jl. Karya Timur - Jl. } \\
\text { Mahakam - Jl. W. R. Supratman - } \\
\text { Jl. Panglima Sudirman }- \text { Jl. } \\
\text { Patimura - Jl. Trunojoyo - Jl. } \\
\text { Kertanegara - Jl. Tugu - Jl. } \\
\text { Kahuripan - Jl. Semeru - Jl. Ijen - } \\
\text { Jl. Retawu - Jl. Bondowoso - Jl. } \\
\text { Jombang - Jl. Suroboyo - Jl. } \\
\text { Jakarta - Jl. Bogor - Jl. Veteran - } \\
\text { Jl. Sumbersari - Terminal } \\
\text { Landung Sari }\end{array}$ & $\begin{array}{l}\text { Terminal Landung Sari }-\mathrm{Jl} \text {. } \\
\text { Tlogomas - Jl. Mayjen Haryono Jl. } \\
\text { Gajayana - Jl. Veteran - Jl. } \\
\text { Bandung - Jl. Ijen - Jl. Semeru - } \\
\text { Jl. Kahuripan - Jl. Tugu - Jl. } \\
\text { Kertanegara - Jl. Trunojoyo - Jl. } \\
\text { Patimura - Jl. Panglima Sudirman } \\
\text { - Jl. WR. Supratman - Jl. } \\
\text { Mahakam - Jl. Karya Timur - Jl. } \\
\text { Tenaga - Jl. Laksamana Adi } \\
\text { Sucipto - Jl. R. Panji Suroso - } \\
\text { Terminal Arjosari }\end{array}$ \\
\hline
\end{tabular}

3. LDG 170 Terminal Landung Sari - Jl. Terminal Gadang - Jl. Kol. Mayjen MT. Haryono - Jl. Sugiono - Jl. Sartono SH - Jl. Irian Mayjen Panjahitan - Jl. Brigjen S. Jaya - Jl. Tanimbar - Jl. Sulawesi Riyadi - Jl. Jend Basuki Rahmat - - Jl. Yulius Usman - Jl. Syarif Al Jl. Merdeka Barat - Jl. Kauman - Qodri - Jl. Ade Irma Suryani - Jl. Jl. Syarif al Qodri - Jl. Ade Irma Hasyim Ashari - Jl. Kawi - Jl. Suryani - Jl. Pasar Besar - Jl. Bromo - Jl. Buring - Jl. Ijen - Jl. Sersan Harun - Jl. Prof. Moh. Bandung - Jl. Veteran - Jl. Yamin - Jl. Sartono SH - Jl. Kol. Terusan Bogor - Jl. Mayjen Sugiono - Terminal Gadang $\quad$ Panjahitan - Jl. Mayjen haryono Terminal Landung Sari

\begin{tabular}{|c|c|c|c|c|}
\hline 4. & $\mathrm{AG}$ & 300 & $\begin{array}{l}\text { Terminal Arjosari - Jl. Simpang } \\
\text { R. Panji Suroso - Jl. Raden Intan } \\
\text { - Jl. Jend A. Yani - Jl. Letjen S. } \\
\text { Parma - Jl. Letjen Sutuyo - Jl. } \\
\text { Jagung Suprapto - Jl. Basuki } \\
\text { Rahmat - Merdeka Utara - Jl. } \\
\text { Merdeka Timur - Jl. } \\
\text { Sukarjowiryor Panoto - Jl. Pasar } \\
\text { Besar - Jl. Sersan Harun - Jl. Prof } \\
\text { Moh yamin - Jl. Sartono SH - Jl. } \\
\text { Kol Sugiono - Terminal Gadang }\end{array}$ & $\begin{array}{l}\text { Terminal Gadang - Jl. Kol. } \\
\text { Sugiyono - Jl. Sartono SH - Jl. } \\
\text { Irian Jaya - Jl. Tanimbar - Jl. } \\
\text { Sulawesi - Jl. Yulius Usman - Jl. } \\
\text { Syarif Al Qodri - Jl. Kauman - Jl. } \\
\text { H. Ashari - Jl. A. R. Hakim - Jl. } \\
\text { Basuki Rahmat - Jl. Jagung } \\
\text { Suprapto - Jl. Letjen Sutoyo - Jl. } \\
\text { Letjen S. Supratman - Jl. Jend A. } \\
\text { Yani - Jl. Raden Intan - Terminal } \\
\text { arjosari }\end{array}$ \\
\hline 5 & $\mathrm{AT}$ & 44 & 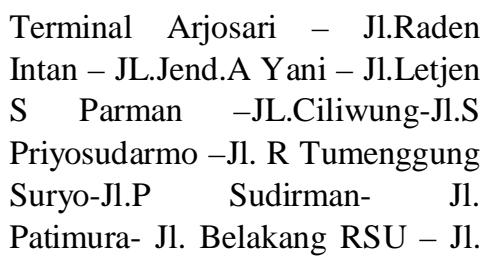 & $\begin{array}{l}\text { Terminal Perum Tidar - Jl. Es. } \\
\text { Berg - Jl. Puncak Mandala - Jl. } \\
\text { Raya Tidar - Jl. Lokon - Jl. Bukit } \\
\text { Barisan -Jl. Galunggung Sangga } \\
\text { Buwana - Jl.Gading- Jl. Wilis - Jl. } \\
\text { Pandan - Jl. Panderman - Jl. Kawi }\end{array}$ \\
\hline
\end{tabular}

Antivirus: Jurnal IImiah dan Teknik Informatika, November 2017, Vol.11, No. 2 


\begin{tabular}{|c|c|c|c|c|}
\hline & & & $\begin{array}{l}\text { Kahuripan }- \text { Jl. Semeru }- \\
\text { Jl.Arjuno - Jl. Kawi }- \text { Jl. } \\
\text { Panderman - Jl. Pandan - Jl. Wilis } \\
\text { - Jl. Gading -Jl. Sangga Buana - } \\
\text { Jl. Galunggung - Jl. Bukit } \\
\text { Barisan - Jl. Lokon -Jl. Raya } \\
\text { Tidar -Jl. Puncak Mandala - } \\
\text { Terminal Perum Tidar }\end{array}$ & $\begin{array}{l}\text { - Jl. Arjuno - Jl. Semeru - Jl. } \\
\text { Kahuripan - Jl. Belakang RSU - } \\
\text { Jl. Patimura - Jl. Panglima } \\
\text { Sudirman - J1. R Tumenggung } \\
\text { Suryo - Jl. S Priyosudarmo - Jl. } \\
\text { Letjen S Parman - Jl. Jend A Yani } \\
\text { - Jl. Raden Intan - Terminal } \\
\text { Arjosari }\end{array}$ \\
\hline 6. & GA & 160 & $\begin{array}{l}\text { Terminal Gadang - Jl. Satsuit } \\
\text { Tubun - Jl. S Supriyadi - Jl. Arif } \\
\text { Margono - Jl. Ade Irma Suryani - } \\
\text { Jl. KH Wahid Hasyim -Jl. } \\
\text { Kauman - Jl. Hasyim Asyhari - } \\
\text { Jl. AR Hakim - Jl. Merdeka Utara } \\
\text { - Jl. S Wiryop } \\
\text { ranoto - Jl. Mojopahit - Jl. Tugu - } \\
\text { Jl. Untung Suropati - Jl. Pajajaran } \\
\text { - Jl. Truno Joyo - Jl. } \\
\text { Cokroaminoto - Jl. Dr Cipto - Jl. } \\
\text { Pang Sudirman - Jl. WR } \\
\text { Supratman - Jl. Letjend Sutoyo - } \\
\text { Jl. Letjend S. Parman - Jl. Jend } \\
\text { Ayani - Jl. R Intan - Terminal } \\
\text { Arjosari }\end{array}$ & $\begin{array}{l}\text { Terminal Arjosari - Jl. Simpang } \\
\text { Panji Suroso - Jl. R Intan - Jl. Jend } \\
\text { A Yani - Jl. Letjend S Parman - Jl. } \\
\text { Letjend Sutoyo - Jl.Indragiri - Jl. } \\
\text { Mahakam - Jl. WR Supratman - } \\
\text { Jl. Pang Sudirrman - Jl. Patimura } \\
\text { Jl. Truno Joyo - Jl. Kertanegara - } \\
\text { Jl. Tugu - Jl. Mojopahit - JL. S } \\
\text { Wiryopranoto - Jl. Sultan Syahrir } \\
\text { - Jl. Halmahera - Jl. Tanimbar - J1 } \\
\text { Arif Margono - Jl. S Supriyadi - } \\
\text { Jl. Satsuit Tubun -Terminal } \\
\text { Gadang }\end{array}$ \\
\hline 7. & TSG & 27 & $\begin{array}{l}\text { Pasar Tawangmangu }- \text { Jl. } \\
\text { Gilimanuk }- \text { Tembalangan }- \text { Jl. } \\
\text { Sukarno Hatta }- \text { Jl. MT Haryono } \\
\text { Jl. Gajayana }- \text { Jl. Bend Sigura - } \\
\text { gura - Apk Gasek }\end{array}$ & $\begin{array}{l}\text { Apk Gasek - Jl. Bend Sigura-gura } \\
\text { - Jl. Gajayana Jl. MT Haryono - } \\
\text { Jl. Sukarno Hatta }- \text { Tembalangan } \\
\text { Jl. Gilimanuk }- \\
\text { Tawangmangu }\end{array}$ \\
\hline 8. & LG & 118 & $\begin{array}{l}\text { Terminal Landungsari - Jl. Tlogo } \\
\text { Mas - Jl. Mayjend Haryono Jl. } \\
\text { Sumber Sari - Jl. Bendungan } \\
\text { Sutami - Jl. Surabaya - Jl. } \\
\text { Bondowoso - Jl. Gading - Jl. } \\
\text { Wilis - Jl. Panderman - Jl. AR } \\
\text { Hakim - Jl. Merdeka Utara - Jl. } \\
\text { Merdeka Selatan - Jl. } \\
\text { Wiryopranoto - Jl. Sultan Syahrir } \\
\text { - Jl. Kyai Tamin - Jl. Sartono SH } \\
\text { - Jl. Peltu Sujono - Jl. Susanto - } \\
\text { Jl. Niaga - Jl. Sonokeling - Jl. }\end{array}$ & $\begin{array}{l}\text { Terminal Gadang - Jl. Satsuit } \\
\text { Tubun - Jl. S Supriyadi - Jl. Janti } \\
\text { - Jl. Sonokeling - Jl. Niaga - } \\
\text { Jl.Halmahera - Jl. Tanimbar - Jl. } \\
\text { Nusa Kambangan - Jl. Terusan } \\
\text { Halmahera - Jl. Kapten Piere } \\
\text { Tendean - Jl. Arif Margono - Jl. } \\
\text { KH Hasyim Asyhari - Jl. Kawi - } \\
\text { Jl. Gading - Jl. Jombang - Jl. } \\
\text { Surabaya - Jl. Bendungan Sutami } \\
- \text { Jl. Wonogiri - Jl. Bend } \\
\text { Sengguruh - Bendungan Sigura- }\end{array}$ \\
\hline
\end{tabular}




\begin{tabular}{|c|c|c|c|c|}
\hline & & & $\begin{array}{l}\text { Janti - Jl. S. Supriyadi - Jl. Satsuit } \\
\text { Tubun - Terminal Gadang }\end{array}$ & $\begin{array}{l}\text { gura - Jl. Sumbersari }-\mathrm{Jl} . \\
\text { Gajayana - Jl. Mayjen Haryono - } \\
\text { Terminal Landungsari }\end{array}$ \\
\hline 9. & MK & 62 & $\begin{array}{l}\text { Term Madyopuro - Jl. Kiageng } \\
\text { Gribik - Jl. Muharto - Jl. Z. Zakse } \\
\text { - Jl. Pasar Besar - Jl. Zaenal } \\
\text { Arifin - Jl. A Munandar - Jl. } \\
\text { MGR Sugriwiryopranoto - Jl. } \\
\text { Merdeka Timur - Jl. Merdeka } \\
\text { Selatan - Jl. Kauman - Jl. KH } \\
\text { Hasyim Asyhari - Jl. Kawi - Jl. } \\
\text { Ijen - Jl. Pahlawan Trib - Jl. } \\
\text { Surabaya - Jl. B. Sutami - Jl. } \\
\text { Kleseman - APK Karang Besuki }\end{array}$ & $\begin{array}{l}\text { APK Karang Besuki }- \text { Jl. } \\
\text { Klaseman - Jl. B Sutami - Jl. } \\
\text { Surabaya - Jl. Pahlawan Trib - Jl. } \\
\text { Guntur - Jl. BS. Riyadi - Jl. } \\
\text { Buring - Jl. Merapi - Jl. Bromo - } \\
\text { Jl. Semeru - Jl. Kahuripan - Jl. } \\
\text { Tugu - Jl. Mojopahit - Jl. Basuki } \\
\text { Rahmad - Jl. Merdeka Utara - Jl. } \\
\text { Merdeka Timur - Jl. MGR } \\
\text { Sugriwiryopranoto - Jl. S. Sah rir - } \\
\text { Jl. Kyai Tamin - Jl. Kopral } \\
\text { Ustman - Jl. Pasar Besar - Jl. } \\
\text { Gatot Subroto - Jl. Ir. H. Juanda - } \\
\text { Jl. Muharto - Jl. Ki Ageng Gribik } \\
\text { - Term Madyopuro }\end{array}$ \\
\hline 10 & MM & 68 & $\begin{array}{l}\text { Term Mulyorejo - Jl. Raya } \\
\text { Bandulan - Jl. Jupri - Jl. Raya } \\
\text { Langsep - Jl. Raya Dieng - Jl. } \\
\text { Kawi Atas - Jl. Kawi - Jl. A.R. } \\
\text { Hakim - Jl. Merdeka Utara - Jl. } \\
\text { MGR. Sugriwiryopranoto - Jl. } \\
\text { Mojopahit - Jl. Tugu }- \text { Jl. } \\
\text { Kertanegara - Jl. Trunojoyo - Jl. } \\
\text { Pattimura - Jl. Urip Sumoharjo - } \\
\text { Jl. M. Wiyono - Jl. Ranu Grati - } \\
\text { Jl. Danau Toba - Jl. Ki Ageng } \\
\text { Gribig - Term Madyopuro }\end{array}$ & $\begin{array}{l}\text { Term Madyopuro - Jl. Ki Ageng } \\
\text { Gribik - Jl. Danau Toba - Jl. Ranu } \\
\text { Grati - Jl. M. Wiyono - Jl. Urip } \\
\text { Sumoharjo - Jl. Pattimura - Jl. } \\
\text { Trunojoyo - Jl. Kertanegara - Jl. } \\
\text { Tugu - Jl. Mojopahit - Jl. Basuki } \\
\text { Rahmad - Jl. Merdeka Barat - Jl. } \\
\text { Kauman - Jl. KH Hasyim Asyhari } \\
\text { - Jl. Kawi - Jl. Kawi Atas - Jl. } \\
\text { Raya Dieng - Jl. Raya Langsep - } \\
\text { Jl. Jupri - Jl. Raya Bandulan - } \\
\text { Term Mulyorejo }\end{array}$ \\
\hline 11 & AJG & 78 & $\begin{array}{l}\text { Term Arjosari - Jl. RP. Suroso - } \\
\text { Jl. Adi Sucipto - Jl. A. Yani - Jl. } \\
\text { S. Parman - Jl. Letjen Sutoyo - Jl. } \\
\text { Indragiri - Jl. RT. Suryo - Jl. } \\
\text { Hamid Rusdi - Jl. Kesatrian - Jl. } \\
\text { Terusan Pahlawan - Jl. Urip } \\
\text { Sumoharjo - Jl. Pattimura - Jl. } \\
\text { Trunojoyo - Jl. Jembatan } \\
\text { Pahlawan - Jl. Ir Juanda - Jl. } \\
\text { Zakse - Jl. RE. Martadinata - Jl. } \\
\text { Kyai Tamin - Jl. Prof M. Yamin - }\end{array}$ & $\begin{array}{l}\text { Term Gadang - Jl. Satsuit Tubun - } \\
\text { Jl. S. Supriayadi - Jl. Janti - Jl. } \\
\text { Sonokeling - Jl. Niaga - Jl. } \\
\text { Susanto - Jl. P. Sujono - Jl. } \\
\text { Sartono SH - Jl. RE Martadinata - } \\
\text { Jl. Kyai Tamin - Jl. Kopral Usman } \\
\text { - Jl. Pasar Besar - Jl. . Arifin - Jl. } \\
\text { Aris Munandar - Jl. Jembatan } \\
\text { Pahlawan - Jl. Trunojoyo - = Jl. } \\
\text { Cokro Aminoto - Jl. Dr. Cipto - Jl. } \\
\text { P. Sudirman - Jl. RT. Suryo - JL. }\end{array}$ \\
\hline
\end{tabular}




\begin{tabular}{|c|c|c|c|c|}
\hline & & & $\begin{array}{l}\text { JL. P. Sujono - Jl. Susanto - Jl. } \\
\text { Niaga - Jl. Sonokeling - Jl. Janti - } \\
\text { Jl. S. Supriyadi - Jl. Satsuit Tubun } \\
\text { - Term Gadang }\end{array}$ & $\begin{array}{l}\text { Barito - Jl. Mahakam - Jl. Karya } \\
\text { Timur - Jl. Ciliwung - Jl. Letjend } \\
\text { S. Parman - Jl. A. Yani - Jl. R. } \\
\text { Intan - Term Arjosari }\end{array}$ \\
\hline 12 & $\mathrm{ABG}$ & 85 & $\begin{array}{l}\text { Term Arjosari - Jl. Simp. RP } \\
\text { Suroso - Jl. R. Intan - Jl. A. Yani } \\
\text { - Jl. Borobudur - Jl. Sukarno } \\
\text { Hatta - Jl. Cengkeh - Jl. } \\
\text { Kalpataru - Jl. Melati - Jl. Mawar } \\
- \text { Jl. Saranagan - Jl. } \\
\text { Tawangmangu - Jl. Kaliurang - } \\
\text { Jl. WR. Supratman - Jl. P. } \\
\text { Sudirman - Jl. Pattimuara - JL. } \\
\text { Trunojoyo - Jl. Jembatan } \\
\text { Pahlawan - Jl. Gatot Subroto - Jl. } \\
\text { L. Martadinata - Jl. Kol Sugiyono } \\
\text { - Term Gadang }\end{array}$ & $\begin{array}{l}\text { Term Gadang - Jl. Kol Sugiyono - } \\
\text { Jl. L. Martadianta - Jl. Gatot } \\
\text { Subroto - Jl. Jembatan Pahlawan - } \\
\text { Jl. Trunojoyo - Jl. Cokro Aminoto } \\
\text { - Jl. Dr. Cipto - Jl. P. Sudirman - } \\
\text { Jl. WR. Supratman - Jl. Kaliaurang } \\
\text { - Jl. Tawangmangu - Jl. Sarangan } \\
\text { - Jl. Mawar - Jl. Bungur - Jl./ } \\
\text { Kalpataru - Jl. Cengkeh - Jl. } \\
\text { Sukarno Hatta - Jl. Borobudur - Jl. } \\
\text { A. yani - Jl. R. Intan - Term } \\
\text { Arjosari }\end{array}$ \\
\hline 13 & AMG & 217 & $\begin{array}{l}\text { Term Arjosari - Jl. Simp SP. } \\
\text { Suroso - Jl. S. Priyo Sudarmo - Jl. } \\
\text { RT Suryo - Jl. Hamid Rusdi - Jl. } \\
\text { Kesatriaan Terusan - Jl. Urip } \\
\text { Sumoharjo - Jl. P. Sudirman - Jl. } \\
\text { Ir Juanda - Jl. Kebalon - Jl. Kol } \\
\text { Sugiyono - Term Gadang }\end{array}$ & $\begin{array}{l}\text { Term Gadang - Jl. Kol. Sugiyono } \\
\text { - Jl. L. Martadinata - Jl. Kyai } \\
\text { Tamin - Jl. Kopraql Usman - Jl. } \\
\text { Pasar Besar - Jl. Gatot Subroto - } \\
\text { Jl. Jembatan Pahlawan - Jl. } \\
\text { Trunojoyo - Jl. Cokroaminoto - Jl. } \\
\text { Dr. Cipto - Jl. P. Sudirman - Jl. } \\
\text { RT. Suryo - Jl. S. Priyo - Jl. } \\
\text { Sudarmo - Jl. LA. Sucipto - Jl. R. } \\
\text { Intan - Term Arjosari }\end{array}$ \\
\hline 14 & CKL & 88 & $\begin{array}{l}\text { APK Cemoro Kandang - Jl. Raya } \\
\text { Cemoro Kandang - Jl. Raya } \\
\text { Madyopuro - Jl. Sekarpuro - Jl. } \\
\text { Komplek UNIDA - JL. D. Sentani } \\
\text { - Jl. D. Tigi - Jl. D. Kerinci - Jl. } \\
\text { D. Tondano - Jl. Limboto - Jl. } \\
\text { Raya Sawojajar - Jl. Ranu Grati - } \\
\text { Jl. M. Wiyono - Jl. Kesatrian - Jl. } \\
\text { Hamid Rusdi - Jl. RT. Suryo - Jl. } \\
\text { S. Priyo Sudarmo - Jl. Ciliwung - } \\
\text { Jl. L. Sutoyo - Jl. Kedawung - Jl. } \\
\text { Kalpataru - Jl. Cengkeh - Jl. } \\
\text { Sukarno Hatta - Jl. Simp } \\
\text { Panggung - Jl. Vinolia - Jl. }\end{array}$ & $\begin{array}{l}\text { Term Landungsari - Jl. Raya } \\
\text { Tlogomas - Jl. M. Haryono - Jl. } \\
\text { Keramik - Jl. Vinolia - Jl. Simp } \\
\text { Panggung - Jl. Panggung - Jl.; } \\
\text { Sukarno Hatta - Jl. Cengkeh - Jl. } \\
\text { Kalpataru - Jl. Kedawung - Jl. } \\
\text { Sutoyo - Jl. Hamid Rusdi - Jl. } \\
\text { Kesatrian - Jl. M. Wiyono - Jl. } \\
\text { Ranu Grati - Jl. Raya Sawojajar - } \\
\text { Jl. D. Limboto Barat Ters - Jl. D. } \\
\text { Tandono - Jl. D.Paniai - Jl. Komp } \\
\text { UNIDA - Jl. Sekar Puro - Jl. Tigi } \\
- \text { Jl. D.Sentanu - Jl. Raya } \\
\text { Madyopuro - Jl. Cemoro Kandang }\end{array}$ \\
\hline
\end{tabular}




\begin{tabular}{|c|c|c|c|c|}
\hline & & & $\begin{array}{l}\text { Keramik - Jl. MT. Haryono - Jl. } \\
\text { Tlogomas - Term Landungsari }\end{array}$ & - APK Cemoro Kandang \\
\hline 15 & GML & 41 & 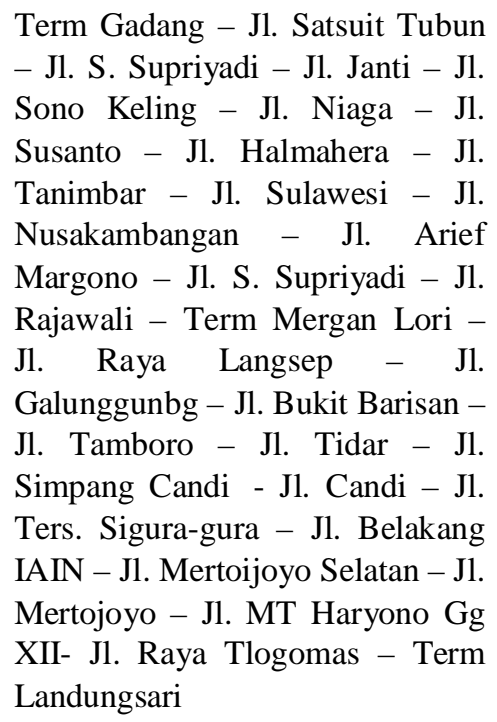 & $\begin{array}{l}\text { Term Landungsari- Jl. Raya } \\
\text { Tlogomas - Jl. MT. Haryono - Jl. } \\
\text { MT.Haryono Gg XII - Jl. } \\
\text { Mertojoyo - Jl. Mertojoyo Selatan } \\
\text { - Jl. Belakang IAIN - Jl. Ters } \\
\text { Sigura-gura - Jl. Candi - Jl. Simp } \\
\text { Candi - Jl. Tidar - Jl. Lokon - Jl. } \\
\text { Bukit Barisan - Jl. Raya Langsep - } \\
\text { Jl. Mergan Lori - Jl. Arief } \\
\text { Margono - Jl. Yulius Usman - Jl. } \\
\text { Sulawesi - Jl. Halmahera - J1. } \\
\text { Susanto - Jl. Niaga - Jl. Sono } \\
\text { Keling - Jl. Janti - Jl. S. Supriyadi } \\
\text { - Jl. S. Tubun - Term Gadang }\end{array}$ \\
\hline 16 & GL & 109 & 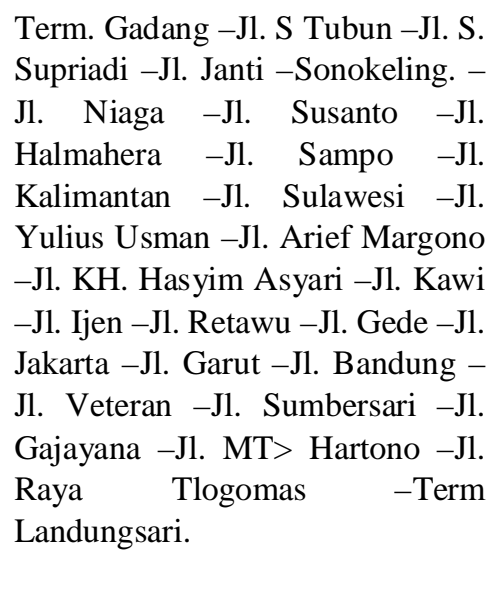 & $\begin{array}{l}\text { Term. Landungsari - Jl. Raya } \\
\text { Tlogomas -Jl. MT. Haryono -Jl. } \\
\text { Gajayana -Jl. Sumbersari - Jl. } \\
\text { Veteran - Jl. Bnadung - Jl. Ijen - } \\
\text { Jl. Semeru - Jl. Arjuno - Kawi - } \\
\text { Jl. AR Hakim - Jl. Merdeka Utara } \\
\text { - Jl. Merdeka Timur - Jl. Kauman } \\
\text { - Jl. KH. Hasyim Asyari - Jl. Arief } \\
\text { Margono - Jl. Yulius Usman - Jl. } \\
\text { Sulawesi Jl. Nusakambangan - Jl. } \\
\text { Halmahera - Jl. Susanto - Jl. } \\
\text { Niaga - Jl. Sonokeling - Jl. Janti - } \\
\text { Jl. S. Supriyadi - Jl. S Tubun - } \\
\text { Term Gadang }\end{array}$ \\
\hline 17 & PBB & 61 & $\begin{array}{l}\text { APK Polowijen - Jl. Cakalan - Jl. } \\
\text { Ikan Tombro Timur - Jl. Ikan } \\
\text { Tombro - Jl. Ikana Piranha Atas - } \\
\text { Jl. Ters Ikan Paus - Jl. Ikana Paus } \\
\text { VI - Jl. Ikan Paus - Jl. Simpang } \\
\text { Borobudur - Jl. A. Yani - Jl. } \\
\text { Laksda Adisucipto - Jl. Simp LA } \\
\text { Sucipto - Jl. Warinoi - Jl. }\end{array}$ & $\begin{array}{l}\text { APK Pasar Bunul - Jl. Membrono } \\
- \text { Jl. Wirinoi - Jl. Simp LA. } \\
\text { Sucipto - Jl. Laksda Adi Sucipto - } \\
\text { Jl. A. Yani - Jl. Borobudur - Jl. } \\
\text { Ikan Paus - Jl. Ikan Paus VII - Jl. } \\
\text { Ters Ikan Paus - Jl. Ikan Piranha } \\
\text { Atas - Jl. Ikan Tombro Timur - Jl. } \\
\text { Cakalan - Jl. APK Polowijen }\end{array}$ \\
\hline
\end{tabular}




\begin{tabular}{|c|c|c|c|c|}
\hline & & & $\begin{array}{l}\text { Membrono } \quad-\quad \text { Jl. } \\
\text { Sisingamanganraja - Jl. R. Patah }- \\
\text { Jl. APK Pasar Bunul }\end{array}$ & \\
\hline 18 & TAT & 6 & $\begin{array}{l}\text { APK Tlogowaru - Jl. Raya } \\
\text { Tlogowaru - Jl. Istiqomah - Jl. } \\
\text { Raya Arjowilangun - Jl. Babatan } \\
\text { V - Jl. Wonorejo - Jl. Jembatan } \\
\text { lori - Jl. Kol Sugiono - Jl. Satsui } \\
\text { Tubun - Jl. S. Supriyadi - Jl. APK } \\
\text { Tirtosari }\end{array}$ & $\begin{array}{l}\text { APK Tirtosari - Jl. S. Supriayadi - } \\
\text { Jl. S. Tubun - JL. Kol Sugiyono - } \\
\text { Jl. Jembatan Lori - Jl. Wonorejo - } \\
\text { Jl. Babatan V - Jl. Babatan - Jl. } \\
\text { Raya Arjowilangun - Jl. Istiqomah } \\
- \text { Jl. Raya Tlogowaru - APK } \\
\text { Tlogowaru }\end{array}$ \\
\hline 19 & JPK & 54 & $\begin{array}{l}\text { Perum Joyo Grand - Jl. Tamansari } \\
\text { - Jl. Joyosuryo - Jl. Mertojoyo - } \\
\text { Jl. Tambaksari - Jl. Simp } \\
\text { GajaHyana - Jl. Gajahyana - Jl. } \\
\text { MT. Haryono - Jl. Sukarno Hatta } \\
\text { - Jl. Pisang Kipas - Jl. Vinolia - } \\
\text { Jl. Tunggul Wulung - Jl. } \\
\text { Arkodion - Jl. Biola - Jl. Ikan } \\
\text { Gurami - Jl. Ikan Kakap - Jl. } \\
\text { Piranha Atas - Jl. Piranha - Jl. A. } \\
\text { Yani - Jl. Cerme - Jl. Balearjosari } \\
\text { - Jl. Karang Asem - Jl. APK } \\
\text { Karanglo Indah }\end{array}$ & $\begin{array}{l}\text { APK Karanglo Indah - Jl. Karang } \\
\text { Asem - Jl. Cerme - Jl. A. Yani - } \\
\text { Jl. Ikan Piranha - Jl. Piranha Atas } \\
\text { - Jl. Ikan Kakap - Jl. Ikan Gurami } \\
\text { - Jl. Biola - Jl. Arkodion - Jl. } \\
\text { Tunggul Wulung - Jl. Bunga } \\
\text { Vinolia - Jl. Pisang Kipas - Jl. } \\
\text { Sukarno Hatta - Jl. MT.Haryono - } \\
\text { Jl. Gajahyana - Jl. Simp } \\
\text { Gajahyana - Jl. Tambaksari - Jl. } \\
\text { Mertojoyo - Jl. Joyo Suryo - Jl. } \\
\text { Tamansari - APK Joyo Grand }\end{array}$ \\
\hline 20 & JDM & 49 & $\begin{array}{l}\text { APK Perum Joyo Grand }- \text { Jl. } \\
\text { Kanjuruan - Jl. Tlogosari - Jl. } \\
\text { Tlogo Indah - Jl. Raya Tlogomas } \\
\text { - Jl. MT. Haryono - Jl. MT } \\
\text { Haryono Gg X - Jl. Joyoraharjo - } \\
\text { Jl. Tambaksari - Jl. Simp } \\
\text { Gajayana - Jl. Gajayana - Jl. } \\
\text { Sumbersari - Jl. Bendungan } \\
\text { Sutami - Jl. Galunggung - Jl. } \\
\text { Raya Langsep - APK Mergan }\end{array}$ & $\begin{array}{l}\text { APK Mergan - Jl. Raya Langsep - } \\
\text { Jl. Galunggung - Jl. Bendungan } \\
\text { Sutami - Jl. Sumbersari - Jl. } \\
\text { Gajayana - Jl. Simp Gajahyana - } \\
\text { Jl. Tambaksari - Jl. Joyoraharjo - } \\
\text { Jl. MT. Haryono Gg X - Jl. MT } \\
\text { Haryono - Jl. Raya Tlogomas - Jl. } \\
\text { Tlogo Indah - Jl. Tlogosari - Jl. } \\
\text { Kanjuruan - APK Joyo Grand }\end{array}$ \\
\hline 21 & MKS & 11 & $\begin{array}{l}\text { Term Mulyorejo }- \text { Jl. Raya } \\
\text { Mulyorejo - Jl. Raya Bakalan } \\
\text { Krajan - Jl. Kemantren Gg III - } \\
\text { Jl. Klayatan Gg III - Jl. S. } \\
\text { Supriyadi - Jl. APK Pasar Sukun }\end{array}$ & $\begin{array}{l}\text { APK Pasar Sukun - Jl. S. } \\
\text { Supriyadi - Jl. Klayatan Gg III - } \\
\text { Jl. KemaNtren Gg III - Jl. Raya } \\
\text { Bakalan Krajan - Jl. Mulyorejo - } \\
\text { Ter Mulyorejo }\end{array}$ \\
\hline
\end{tabular}




\begin{tabular}{|c|c|c|c|c|}
\hline 22 & TST & 83 & $\begin{array}{l}\text { Sub Term Tlogowaru - Jl. Perum } \\
\text { Puri Cempaka Putih - Jl. Raya } \\
\text { Arjowilangun - Jl. Wonorejo - Jl. } \\
\text { K. Parseh Jaya - Jl. M. Sungkono } \\
\text { - Jl. Muharto - Jl. Puntodewa - Jl. } \\
\text { Kalimasada - Jl. M. Wiyono - Jl. } \\
\text { Kesatrian - Jl. Untung Suropati - } \\
\text { Jl. P. Sudirman - Jl. WR. } \\
\text { Supratman - Jl. L. Sutoyo - Jl.; } \\
\text { Sarangan - Jl. Sarangan Atas - Jl. } \\
\text { Selorejo - Jl. Selorejo Blok A - Jl. } \\
\text { Selorejo Blok B - Jl. Mawar - Jl. } \\
\text { Setaman - Jl. Melati - Jl. Bungur } \\
\text { - Jl. Cengger Ayam - Jl. Cengger } \\
\text { Ayam I - Jl. Ters Kendalsari - Jl. } \\
\text { Bukirsari - Jl. Ters Candi Mendut } \\
\text { - Jl. C. Bima -JL. C. Badut - Jl. } \\
\text { C. Sari Utara - Jl. Sudimoro - Jl. } \\
\text { Ikan Kakap - Jl. Ikan Tombro - } \\
\text { Jl. Ikan Tombro Barat - JL. } \\
\text { KH.Yuuf Timur - Jl. KH Yusuf } \\
\text { Barat - Jl. Ds Jeruk - Jl. Joyo } \\
\text { Utama - APK Tasik Madu }\end{array}$ & $\begin{array}{l}\text { APK Tasik Madu - Jl. Joyo utomo } \\
\text {-jl. KH.Yusuf Timur Jl. Ikan } \\
\text { Tombro Barat - Jl. Ikan Tombro - } \\
\text { Jl. Kakap - Jl. C. sari - Jl. C. } \\
\text { Mendut - Jl. Ters .C. Mendut - Jl. } \\
\text { Bukit Sari -Jl. Cengger Ayam I - } \\
\text { Jl. Cengger Ayam - Jl. Melati - Jl. } \\
\text { Setaman - Jl. Mawar -Jl. Selorejo } \\
\text { Blok B - Jl. Selorejo Blok A Jl. } \\
\text { Sarangan Atas - Jl. Sarangan - Jl. } \\
\text { L. Sutoyo - Jl. WR. Supratman - } \\
\text { Jl. P. Sudirman Utara . - Jl. P. } \\
\text { Sudirman Utara -Jl. Untung } \\
\text { Suropati Utara - Jl. Kesatrian - Jl. } \\
\text { M. Wiyono - Jl. Kalimasodo - Jl. } \\
\text { Puntodewo - Jl. Muharo - Jl. Jl. } \\
\text { M.Sungkono - Jl. K. Parseh Jaya - } \\
\text { Jl. Wonorejo - Jl. Arjowilangun - } \\
\text { Jl. Perum. Putri Cempaka Putih - } \\
\text { Sub. Term. Putri Cempaka Putih - } \\
\text { Sub . Term. Tlogo waru. }\end{array}$ \\
\hline 23 & GM & 53 & $\begin{array}{l}\text { Term. Gadang - Jl. Kol. Sugiono . } \\
\text { - Jl. Susanto - Jl. Irian Jaya - Jl. } \\
\text { Tanimbar. - Jl. Sulaesi. - Jl. } \\
\text { Yulius Usman . - Jl. Syarief Al } \\
\text { Qodri - Jl. A. I Suryani - Jl. B. } \\
\text { Katamso - Jl. Ir Rais - J1. Jupri - } \\
\text { Jl. Bandulan - Jl. Raya Mulyrejo - } \\
\text { Sub term Mulyorejo. }\end{array}$ & $\begin{array}{l}\text { Term. Mulyorejo. - Jl. Raya } \\
\text { Mulyorejo - Jl. Ds. Tebo Selatan - } \\
\text { Jl. Raya Mulyo rejo. - Jl. Raya } \\
\text { Bandulan . - Jl. Jupri. - Jl. IR. Rais } \\
\text { - Jl. B> Katamso. - Jl. A. I. } \\
\text { Suryani. - Jl. Sukarjowiryopranoto } \\
\text { - Jl. Kyai Tamin - Jl. Prof. M. } \\
\text { Yamin. - Jl. Susanto. - Jl. Kol. } \\
\text { Sugiono - Jl. Term. Gadang. }\end{array}$ \\
\hline 24 & ASD & 46 & $\begin{array}{l}\text { Term. Arjosari -Jl. Simp. PR. } \\
\text { Suroso -JL. PR. Suroso -Jl. } \\
\text { Plaosan TMR -Jl. Tl. Grajakan - } \\
\text { Jl. Sucipto -Jl. Simp. Batu Bara - } \\
\text { Jl. Batu Bara -Jl. LA. Sucipto -Jl. } \\
\text { Tembaga -Jl. Simp. Emas -Jl. } \\
\text { Emas -Jl. Sulfat -Jl. RT. Suryo - } \\
\text { Jl. Sanan -Jl. Barito -Jl. Mahakam } \\
\text {-Jl. Indragiri -Jl. Letjend Sutoyo } \\
\text {-Jl. Sarangan -Jl. Mawar -Jl. } \\
\text { Bungur -Jl. Melati -Jl. Kalpataru }\end{array}$ & $\begin{array}{l}\text { APK Puncak Dieng }-\mathrm{Jl} \text {. Ters } \\
\text { Dieng -Jl. Raya Langsep }-\mathrm{Jl} \text {. } \\
\text { Mundu -Jl. Kawi Atas -Jl. Taman } \\
\text { Wilis -Jl. Klampok Kasri }-\mathrm{Jl} \text {. } \\
\text { Bondowoso -Jl. Gresik }-\mathrm{Jl} \text {. } \\
\text { Surabaya -Jl. Jakarta -Jl. Simp } \\
\text { Bogor -Jl. Veteran -Jl. Bogor -Jl. } \\
\text { Jl. M Panjaitan -Jl. Sukarno Hatta } \\
\text {-Jl. Cengkeh -Jl. Kalpataru -Jl. } \\
\text { Melati -Jl. Mawar -Jl. Sarangan - } \\
\text { Jl. Letjend Sutoyo -Jl. Indragiri - }\end{array}$ \\
\hline
\end{tabular}


-Jl. Cengkeh -Jl. Sukarno Hatta - Jl. Sanan -Jl. RT. Suryo -Jl. Sulfat Jl. M. Panjaitan -Jl. Bandung -Jl. -Jl. Emas -Jl. Simp Emas -Jl. Garut -Jl. Jakarta -Jl. Surabaya - Tembaga -Jl. Batu Bara -Jl. Simp Jl. Gresik -Jl. Bondowoso -Jl. Batu Bara-Jl. LA. Sucipto -Jl. TL Klampok Kasri -Jl. Taman Wilis Grajakan -Jl. Plaosan Timur -Jl. -Jl. Kawi Atas -Jl. Mundu -Jl. RP Suroso -Jl. R. Intan -Term Raya Langsep -Jl. Ters Dieng - arjosari AKP Puncak Dieng.

\section{(b) Pencarian Rute}

Dari proses pemberian bobot pada node-node jalan dan persimpangannya, kemudian dapat diproses untuk pencarian jalurnya. Pada Gambar Gambar 6 akan ditampilkan pencarian rute angkot terdekat. Pada laman tersebut, user dapat mengakses rute dengan menuliskan posisi asal dan tujuannya.

ANIGKRTM Home Daffar Angkot Daftar Teminal Pengaauan Rute

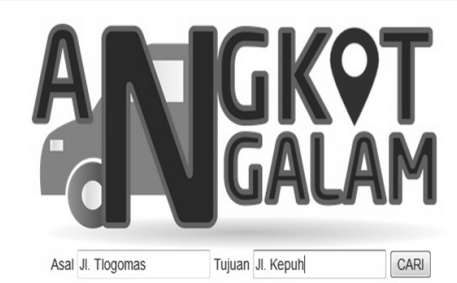

Gambar 6 Laman Pencarian Rute

Studi kasus menggunakan posisi awal Jl. Tlogomas kemudian tujuannya adalah kawasan Jl. Kepuh, maka dihasilkan output dari aplikasi sebagaimana tertera pada Gambar 7 berikut. Sebagai rekomendasi untuk menggunakan angkot jalur HL ataupun HML.

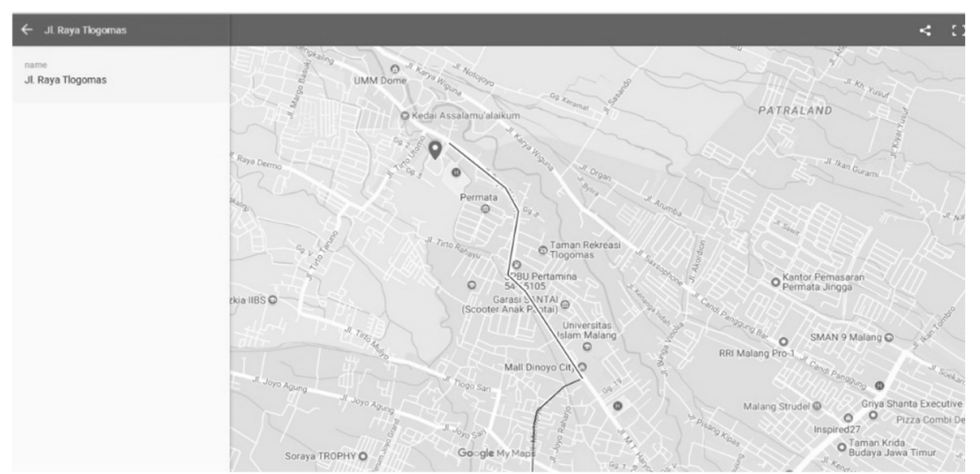

Gambar 7 Hasil Pencarian 


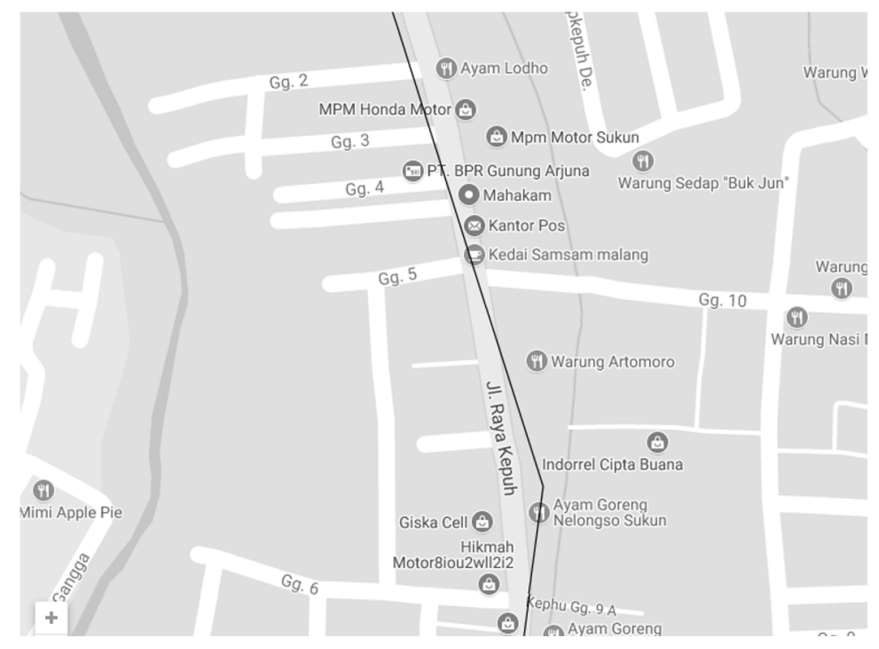

Gambar 8 Hasil Pencarian / Lokasi Tujuan

\section{SimpUlan DAN SARAN}

\section{A. Simpulan}

Prototipe sistem pencarian jalur angkot terdekat. Dengan memperhatikan hasil-hasil penelitian yang telah diperoleh dapat disimpulkan hal-hal berikut.

1. Output aplikasi sudah menunjukkan hasil yang bagus dengan membandingkan dengan cara konvensional

2. Proses yang sedikit lambat dikarenakan membutuhkan koneksi internet yang stabil.

3. Metode yang dipakai hanya mampu mengadopsi satu parameter yakni jarak.

4. Penelitian yang telah dilakukan menghasilkan desain, analisis, dan pembuatan

\section{B. Saran}

Untuk mendapatkan hasil dari pencarian jalur yang valid, diperlukan beberapa pengembangan dan penelitian saling mendukung. Pengembangan dapat dilakukan dengan membuat aplikasi yang berbasis GIS dan dapat berjalan di mobile platform. Selain itu pula, untuk memproses parameter dari kasus yang lebih kompleks, maka dapat diterapkan metode lain sehingga keputusan yang didapat menjadi lebih valid. 


\section{Daftar Pustaka}

Jogiyanto, H. M. 2001. Analisis dan Desain Sistem Informasi: Pendekatan Terstruktur Teori dan Praktek Aplikasi Bisnis. Yogyakarta: Penerbit Andi.

Kadir, A. 2003. Pengenalan Sistem Informasi. Yogyakarta: Penerbit Andi.

Nugroho. B. 2005. Database Relational Dengan MySQL. Yogyakarta: Andi.

Peranginangin, K. 2006. Aplikasi Web dengan PHP dan MySQL. Yogyakarta: Andi.

Praditya, Alfin. 2011. Graph Theory Lecture Note Part-1. Online at: www.scribd.com/doc/59610412/Graph-Theory-Lecture-Note-Part-1,

Ramadhan, Arif. 2006. Pemrograman Web Menggunakan HTML, CSS, dan Javascript. Jakarta: Elex Media Computindo. 